\title{
Screening Winter-sown Onion Entries for Iris Yellow Spot Virus Tolerance
}

\author{
Parminder S. Multani ${ }^{1}$ and Christopher S. Cramer ${ }^{2,5}$ \\ Department of Plant and Environmental Sciences, New Mexico State \\ University, Box 30003, MSC 3Q, Las Cruces, NM 88003-8003
}

\author{
Robert L. Steiner ${ }^{3}$ \\ Department of Economics and International Business, New Mexico State \\ University, Las Cruces, NM 88003-8003
}

\section{Rebecca Creamer ${ }^{4}$ \\ Department of Entomology, Plant Pathology and Weed Science, New Mexico State University, Las Cruces, NM 88003-8003}

\section{Additional index words. Allium cepa, disease rating, ELISA, RT-PCR}

\begin{abstract}
Identification of resistant or tolerant onion (Allium cepa L.) cultivars is crucial for the development of integrated management strategies for Iris yellow spot virus (IYSV). Exclusively vectored by onion thrips (Thrips tabaci), IYSV is a potentially devastating tospovirus of onion that has been confirmed to be present in 15 countries all over the world. In this study, 18 winter-sown onion entries were screened for IYSV symptom expression over two seasons. Over the growing season, straw-colored, necrotic lesions typical of IYSV infection were observed and rated for disease severity. Entries, NMSU 03-52-1, NMSU 04-41, NMSU 04-44-1, and 'NuMex Jose Fernandez', exhibited fewer symptoms than many other entries tested. 'Caballero', NMSU 04-57-1, NMSU 0478-1, and 'Cimarron' exhibited more symptoms. Disease progression over time was rapid for entries exhibiting more symptoms and slow for entries exhibiting fewer symptoms. Enzyme-linked immunosorbent assay (ELISA) optical densities correlated poorly with the severity of disease symptoms. Trends in the disease progression over time emphasize the importance of rating IYSV symptoms late in the crop's development and to search for delayed disease progression rather than early symptom expression to determine IYSV susceptibility.
\end{abstract}

Iris yellow spot virus (IYSV) infects several crops of commercial importance with the most damage being observed on onion (Allium cepa L.) (Cortês et al., 1998; Gera et al., 1998). IYSV has been confirmed in 15 countries (Gent et al., 2006; Hoepting et al., 2008; Huchette et al., 2008; Ward et al., 2008) and has been associated with up to a $100 \%$ loss in onion bulb and seed crops in Brazil (Pozzer et al., 1999) and losses of 50\% to $60 \%$ in onion bulb production in Israel (Kritzman et al., 2001). In the United States, IYSV has spread rapidly to all major onionproducing states causing severe damage to onion bulb and seed crops (Creamer et al., 2004; Crowe and Pappu, 2005; du Toit et al.,

\footnotetext{
Received for publication 26 Jan. 2009. Accepted for publication 5 Mar. 2009.

This research was funded by the NMSU Agricultural Experiment Station and the New Mexico Dry Onion Commission.

The cost of publishing this paper was defrayed in part by the payment of page charges. Under postal regulations, this paper therefore must be marked advertisement solely to indicate this fact.

${ }^{1}$ Graduate Research Assistant.

${ }^{2}$ Professor of Horticulture.

${ }^{3}$ Professor of Experimental Statistics.

${ }^{4}$ Associate Professor of Plant Virology.

${ }^{5}$ To whom reprint requests should be addressed; e-mailcscramer@nmsu.edu.
}

may be associated with volunteer onion bulbs from the previous year's production or may be present in onion plant debris. In addition, transplants, already infected with IYSV or harboring viruliferous onion thrips, may be imported into a local production region (Gent et al., 2006; Schwartz et al., 2008). All of these sources may contribute to the early IYSV infection of plants. Control of IYSV requires an integrated approach, including control of the vector, cultural practices, and genetic resistance/tolerance (Gent et al., 2006; Schwartz et al., 2008). The primary means of controlling onion thrips is with insecticides, which has become more challenging as a result of the development of insecticidal resistance (Allen et al., 2005; Shelton et al., 2003). Plants under disease, salt, nutrient, water, temperature, or other stress generally sustain more damage from IYSV (Gent et al., 2006).

Several investigations have found that onion cultivars differ in their susceptibility to IYSV. However, no onion cultivar or breeding line has been found to be highly resistant to IYSV (Gent et al., 2006). Creamer et al. (2004) reported differences in the IYSV incidence of three onion cultivars in growth chamber tests. du Toit et al. (2004b) rated 46 onion cultivars for IYSV severity and observed significant differences for IYSV susceptibility. IYSV incidence ranged from $58 \%$ to $97 \%$ among different cultivars. Schwartz et al. (2004) reported significant differences for IYSV incidence among onion cultivars when IYSV incidence ranged from $16 \%$ to $100 \%$ in 2003 and $13 \%$ to $61 \%$ in 2004. Shock et al. (2008) found that 'Joaquin', 'Charismatic', and 'Affirmed' expressed some of the lowest IYSV ratings over a 2-year period. For each of these studies, natural IYSV inoculum levels were relied on for infection and disease symptom expression. In addition, tolerance to onion thrips feeding injury and onion thrips feeding preference (Coudriet et al., 1979; Hoffmann et al., 1996; Jones et al., 1934; Molenaar, 1984) may contribute to differences in IYSV incidence among onion entries.

In the absence of effective management measures, the identification of resistant or tolerant cultivars is crucial to the development of integrated management strategies for IYSV. There is a need to identify onion cultivars with better tolerance to IYSV and to determine various factors associated with IYSV symptom development such as virus titer and heat stress. This study was undertaken to screen New Mexico onion entries for tolerance to IYSV infection and of symptom expression and correlate the enzyme-linked immunosorbent assay (ELISA) optical density with IYSV symptom severity at different times during the crop season.

\section{Materials and Methods}

Schwartz et al., 2008), onion cull piles (Nault et al., 2008), alternate crops, and certain weed hosts (Cosmi et al., 2003; Gent et al., 2006; Nischwitz et al., 2007; Sampangi et al., 2007; Schwartz et al., 2008). Gent et al. (2006) go on to speculate that viruliferous onion thrips
Plant materials. Eighteen winter-sown onion entries were selected from released New Mexico onion cultivars, breeding lines from the New Mexico State University onion 
breeding program, and commercial cultivars (Table 1). For the 2005 study, seeds were sown in trays containing Metro-Mix 360 (SUN GRO ${ }^{\circledR}$, Bellevue, WA) on 7 Nov. 2004 and seedlings were grown until they were $15 \mathrm{~cm}$ in height and possessed three to four true leaves before they were transplanted to the field on $23 \mathrm{Feb} .2005$ with a distance of $10 \mathrm{~cm}$ between plants. For the 2006 study, seeds of entries were sown directly into the field on 20 Mar. 2006. Plants were thinned on 23 Apr. 2006 to maintain a distance of $10 \mathrm{~cm}$ between two adjacent plants. Differences in the preparation of plant materials between years was warranted by field management strategies in the first year that required the use of transplanted material rather than directseeded material.

Field design and source of inoculum. Field experiments were conducted at the Leyendecker Plant Science Research Center (Armijo loam, $1178 \mathrm{~m}$ ), $2.5 \mathrm{~km}$ south of Las Cruces, NM. A randomized complete block design with three replications of each entry was used for both years. Each plot consisted of two 5.4-m long rows of onions with $15 \mathrm{~cm}$ between rows and a $60-\mathrm{cm}$ alley between adjacent plots. In 2005, the field was prepared such that onion bulbs from a previous year's IYSV-infected onion research crop were planted in each alternating bed in the field (Fig. 1). In addition, IYSV-infected bulbs were placed in the front and back of the study such that each test plot was surrounded by infected bulbs. The plants that had produced these infected bulbs had been tested in the previous year for the presence of IYSV by ELISA and the presence of IYSV was confirmed. The same field design was followed during the 2006 study with some differences in the location and the distribution of inoculum sources. IYSV-infected bulbs from the previous year were not placed between test plots. It was observed in the previous year that IYSV-infected bulbs that were in their second year of growth stopped producing leaves in April and initiated seedstalk formation. Because onion thrips preferred feeding site is onion leaf axils, these axils would disappear as a result of the presence of a seedstalk growing through this area. With the disappearance of leaf axils on seedstalk formation, it was hypothesized that onion thrips might migrate out of the field in search for other food sources. To provide a supply of leaf axil material longer into the season and to retain onion thrip populations in the field and around the test plots, IYSV-susceptible, short and intermediate breeding lines were fall-sown on 14 Nov. 2005 on alternate beds surrounding the test plots. These plants would not form seedstalks in the next year and would produce preferred feeding sites for onion thrips longer into the growing season before the plants matured. This study was planted next to a similar study where IYSV resistance in fall-sown onion entries was being evaluated and wherein IYSV-infected bulbs were placed on alternate beds. It was anticipated that onion thrips would spread IYSV from these bulbs to the breeding lines in this adjacent winter-sown trial.

Field management. All experiments were managed in a similar manner using standard cultural practices recommended for onion production in southern New Mexico conditions (Corgan et al., 2000). In 2005, irrigation was withheld for the final 2 weeks of observations. No chemical sprays for onion thrips control were applied during the cropping season. A high onion thrips population was desired to ensure IYSV spread throughout the field. In 2005, Treflan 5G (trifluralin; Dow Agrosciences, Midland, MI) was incorporated preplanting to control weed growth. Directseeded onions would not grow in this field as a result of the application of this herbicide. Thus, for the 2005 test year, this herbicide application necessitated the use of onion transplants that were unaffected by the herbicide application. Plots were hand-weeded throughout the season. Fields were furrow-irrigated once per week. Fertilization was applied after the seeds were sown or after plants were transplanted in the field. Plots were harvested when $80 \%$ of the plant tops within the plot were down.

Disease ratings. Starting 30 Mar. 2005 and 1 Apr. 2006, test plots were monitored weekly for the appearance of any IYSV symptoms. Starting 1 June 2005 and 8 June 2006, 10 arbitrarily selected plants per plot were rated weekly for IYSV severity on a scale of 1 to 9 where 1 indicated no IYSV lesions and 9 indicated more than $50 \%$ of leaf tissue for a single plant was damaged as a result of coalescing IYSV lesions (Fig. 2). It was assumed that given enough time, plants that expressed $50 \%$ of leaf tissue damaged would progress to $100 \%$ of leaf tissue damaged. This assumption was made based on past visual observations of disease progression. All ratings were made by the same individual throughout the growing season. Plots were rated on a weekly basis until 6 July 2005 and 13 July 2006 when most of the plants were mature and harvested.

Sample collection. The first samples were collected on 7 June 2005 and 13 June 2006 when disease symptoms ratings ranged from 1 to 4 . The second samples were collected on 28 June 2005 and 17 July 2006 when disease ratings ranged from 2 to 9 . Samples were

Table 1. Average Iris yellow spot virus (IYSV) disease ratings of entries collected at different times over the crop season in 2005 and 2006.

\begin{tabular}{|c|c|c|c|c|c|c|c|c|c|c|c|c|}
\hline \multirow[b]{3}{*}{ Entry } & \multicolumn{12}{|c|}{ Rating dates [number of days post transplanting (2005) or sowing (2006)] ${ }^{\mathrm{z}}$} \\
\hline & \multicolumn{6}{|c|}{2005} & \multicolumn{6}{|c|}{2006} \\
\hline & $\begin{array}{c}1 \text { June } \\
\text { (98) }\end{array}$ & $\begin{array}{l}7 \text { June } \\
\text { (104) }\end{array}$ & $\begin{array}{c}\text { 14 June } \\
\text { (111) }\end{array}$ & $\begin{array}{l}21 \text { June } \\
\text { (118) }\end{array}$ & $\begin{array}{l}28 \text { June } \\
(125)\end{array}$ & $\begin{array}{l}\text { 6 July } \\
\text { (133) }\end{array}$ & $\begin{array}{c}8 \text { June } \\
(80)\end{array}$ & $\begin{array}{c}15 \text { June } \\
(87)\end{array}$ & $\begin{array}{l}22 \text { June } \\
(94)\end{array}$ & $\begin{array}{c}29 \text { June } \\
\text { (101) }\end{array}$ & $\begin{array}{l}\text { 6 July } \\
(108)\end{array}$ & $\begin{array}{c}\text { 14 July } \\
\text { (116) }\end{array}$ \\
\hline Caballero & $1.8^{y}$ & 2.6 & 3.4 & 4.7 & $6.3^{\mathrm{x}}$ & $6.8^{\mathrm{x}}$ & 1.5 & 1.9 & 1.6 & 2.2 & 2.7 & 7.8 \\
\hline Candy & 1.9 & $2.4^{\mathrm{x}}$ & 3.8 & 3.7 & 4.4 & $5.1^{\mathrm{x}}$ & 1.3 & 1.5 & 2.3 & 2.6 & 4.6 & 8.0 \\
\hline Cimarron & 1.5 & 2.6 & 3.2 & 5.0 & 5.7 & 5.9 & 1.5 & 2.1 & 2.3 & 3.0 & 4.1 & 7.9 \\
\hline Excursion & 1.8 & 2.2 & 2.7 & 3.8 & 4.5 & 5.5 & 1.7 & 2.0 & 2.8 & 3.2 & 3.5 & 7.3 \\
\hline Madero & 2.0 & 2.6 & 3.0 & 4.0 & 4.2 & 5.2 & 1.3 & 1.9 & 2.3 & 2.4 & 3.3 & 7.7 \\
\hline NMSU 03-52-1 & $1.4^{\mathrm{x}}$ & $1.6^{\mathrm{x}}$ & $2.0^{\mathrm{x}}$ & $2.7^{x}$ & $2.8^{\mathrm{x}}$ & $4.0^{\mathrm{x}}$ & 1.3 & 1.4 & 1.8 & 1.8 & 3.3 & 4.6 \\
\hline NMSU 04-41 & 1.8 & 2.5 & 3.0 & 3.4 & 4.0 & 4.3 & 1.4 & 1.8 & 1.8 & 2.4 & 3.5 & 5.9 \\
\hline NMSU 04-44-1 & 1.1 & 2.2 & 2.7 & 3.5 & 3.5 & 4.5 & 1.3 & 1.6 & 1.7 & 1.8 & 2.6 & 6.3 \\
\hline NMSU 04-52-1 & 1.2 & 1.4 & 2.0 & 3.5 & $3.5^{\mathrm{x}}$ & $4.9^{\mathrm{x}}$ & 1.3 & 1.6 & 2.7 & 2.2 & 2.9 & 8.3 \\
\hline NMSU 04-52-2 & 1.7 & 2.5 & 3.3 & 4.2 & 4.7 & $5.9^{x}$ & 1.2 & 1.8 & 1.8 & 2.4 & 2.3 & 7.5 \\
\hline NMSU 04-57-1 & $1.3^{\mathrm{x}}$ & $1.8^{\mathrm{x}}$ & $2.7^{x}$ & $3.9^{x}$ & $4.7^{x}$ & $6.2^{\mathrm{x}}$ & 1.2 & 1.6 & 1.8 & 2.2 & 2.4 & 8.1 \\
\hline NMSU 04-78-1 & 1.4 & 1.7 & 1.8 & 3.3 & 3.7 & $5.9^{x}$ & 1.3 & 1.6 & 1.8 & 2.6 & 3.3 & 8.0 \\
\hline NMSU 04-87-1 & 1.2 & 1.6 & 1.6 & 2.7 & 2.9 & 4.5 & 1.0 & 1.5 & 2.0 & 2.1 & 4.1 & 7.0 \\
\hline NuMex Centric & 1.5 & 1.9 & 2.2 & 3.1 & 3.0 & 4.8 & 1.2 & 1.6 & 1.6 & 2.0 & 3.4 & 7.4 \\
\hline NuMex Jose Fern. & 1.2 & 2.0 & 2.0 & 2.7 & 3.1 & 4.6 & 1.4 & 1.5 & 2.0 & 2.3 & 3.9 & 6.6 \\
\hline Rumba & $1.5^{\mathrm{x}}$ & $2.3^{\mathrm{x}}$ & $2.4^{\mathrm{x}}$ & $3.6^{x}$ & $3.2^{\mathrm{x}}$ & $4.6^{x}$ & 1.5 & 1.9 & 1.8 & 1.8 & 2.9 & 7.5 \\
\hline Sierra Blanca & 1.4 & 2.0 & 2.9 & 3.6 & 4.9 & 6.0 & 1.6 & 1.8 & 2.0 & 2.7 & 3.6 & 7.4 \\
\hline SR 4001 & 1.6 & 2.6 & 3.3 & 4.5 & 5.4 & 6.4 & 1.2 & 1.6 & 1.8 & 1.9 & 2.5 & 6.9 \\
\hline Mean & 1.6 & 2.1 & 2.6 & 3.6 & 4.1 & 5.2 & 1.3 & 1.7 & 2.0 & 2.3 & 3.3 & 7.2 \\
\hline Least significant difference $5 \%$ & $0.6^{*}$ & $0.8 *$ & $1.3 *$ & NS & $1.4 * * *$ & $1.3 * *$ & NS & $0.3 * *$ & $0.6^{*}$ & $0.5 * * *$ & $0.9 * * *$ & $1.2 * * *$ \\
\hline
\end{tabular}

${ }^{\mathrm{z}}$ In 2005, seeds were sown in the greenhouse before being transplanted to the field on 23 Feb. In 2006, seeds were sown directly in the field on 20 Mar. ${ }^{y}$ Each cell shows the disease rating of an entry on a particular date averaged over three replications. Ten randomly selected plants from each replication (plot) were rated for IYSV symptoms based on a scale of 1 (no disease symptom) to 9 (50\% or more of the leaf tissue from a single plant was showing symptoms). ${ }^{\mathrm{x}}$ Cells that have a disease rating of an entry averaged over two replications only.

NS, $* * *, * * *=$ Nonsignificant F-test $(17 \mathrm{df})$ for all entry levels at $P=0.05$; significant F-test $(17 \mathrm{df})$ at $P=0.05, P=0.01$, and $P=0.001$, respectively. 
collected from 10 arbitrarily selected plants in each plot, which may or may not have been the same plants rated for IYSV disease severity on that particular date. In addition, the plants chosen for sampling within a single plot would have been different between the two sampling dates. Equal amounts $(\approx 0.5 \mathrm{~g})$ of leaf tissue were collected in 2-mL tubes by bulking the tips from the youngest leaves. The tissue samples may or may not have consisted of symptomatic tissue. In addition, samples were collected arbitrarily from 20 IYSV-infected bulbs or plants that were being used as inoculum sources for the study to confirm IYSV presence in the inoculum. Plant samples were collected to confirm the presence of IYSV by ELISA (Copeland, 1998) and reverse transcription-polymerase chain reaction (RT-PCR) (Cortês et al., 1998). Samples were stored at $-80{ }^{\circ} \mathrm{C}$ for 1 month before they were analyzed.

\begin{tabular}{|l|l|l|l|l|l|l|l|l|l|l|l|l|}
\hline I & I & I & I & I & I & I & I & I & I & I & I & I \\
\hline I & X & I & X & I & X & I & X & I & X & I & X & I \\
\hline I & X & I & X & I & X & I & X & I & X & I & X & I \\
\hline I & X & I & X & I & X & I & X & I & X & I & X & I \\
\hline I & X & I & X & I & X & I & X & I & X & I & X & I \\
\hline I & X & I & X & I & X & I & X & I & X & I & X & I \\
\hline I & X & I & X & I & X & I & X & I & X & I & X & I \\
\hline I & X & I & X & I & X & I & X & I & X & I & X & I \\
\hline I & X & I & X & I & X & I & X & I & X & I & X & I \\
\hline I & X & I & X & I & X & I & X & I & X & I & X & I \\
\hline I & I & I & I & I & I & I & I & I & I & I & I & I \\
\hline
\end{tabular}

Fig. 1. Field layout of test plots (X) and Iris yellow spot virus infected bulbs (I) (2005) or susceptible seedlings that were not infected with Iris yellow spot virus when sown (2006) (I).
Enzyme-linked immunosorbent assay. Indirect ELISA was performed to detect the presence and measure the concentration of IYSV in leaf tissue samples. Tissue samples were frozen in liquid nitrogen and ground to a powder before homogenizing with coating buffer. An equal amount of plant tissue (60 $\mathrm{mg}$ ) was ground in liquid nitrogen and an equal amount was sampled for ELISA testing. The whole procedure was performed according to Copeland (1998) with modification for performing indirect ELISA. Coating antibodies (rabbit IgG antibody) against IYSV nucleoproteins (Agdia, Elkhart, IN) were diluted $1 \times 10^{-3}$ before use, although different lots of antibody were used for analysis of the two sampling dates. Goat antirabbit IgG antibodies conjugated to alkaline phosphatase (Sigma-Aldrich Inc., St. Louis, MO) were diluted $5 \times 10^{-4}$ before use. An EMax ${ }^{\circledR}$ Precision Microplate Reader (Molecular Devices Co., Sunnyvale, CA) was used at a wavelength of $405 \mathrm{~nm}$ to read the relative absorbance (optical density) values of samples in microtiter plates.

On an indicated date, samples from each plot were duplicated in adjacent wells. Mean ELISA absorbance $\left(\mathrm{A}_{405}\right)$ optical density $(\mathrm{OD})$ values for a particular entry were calculated by averaging the values of samples taken from three replicated plots of that entry. Any OD values that were greater than the healthy control value plus four times the SD were considered positive for IYSV.

For the positive control, highly symptomatic onion leaf tissue was obtained from another field at the Fabian Garcia Science Center in Las Cruces, NM, and ground in the coating buffer. To prepare the healthy control, onion seeds were planted in flats containing Metro-Mix 360 (SUN GRO ${ }^{\circledR}$ ) and were grown in a growth chamber to avoid any type of insect pest and potential virus inoculation. Leaf tissue obtained from 6-week-old seedlings was ground in coating buffer. For the blank control, $100 \mu \mathrm{L}$ of coating buffer was added to two wells for each sample run to block binding sites and to avoid any falsepositives.

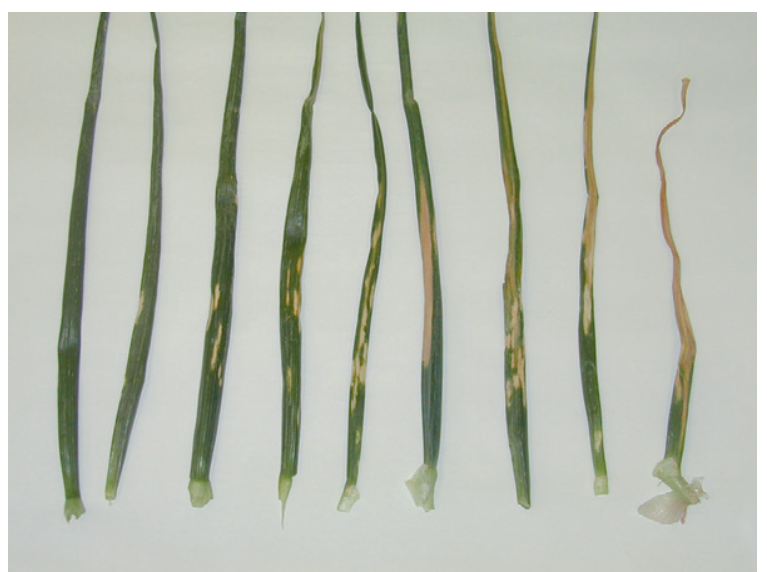

Fig. 2. Iris yellow spot virus symptoms rated from 1 (no disease symptoms) to 9 (50\% or more of leaf tissue is necrotic) (left to right). In the study, individual plants were rated not individual leaves on plants. This figure is presented to illustrate similar symptom severity at different rating values.

Reverse transcription-polymerase chain reaction. Samples that tested positive for IYSV by ELISA were further analyzed by performing RT-PCR. Primer pair, IYSVP1 and IYSVP2, reported by Cortês et al. (1998) was used to amplify the IYSV nucleoprotein (NP) gene from infected tissue samples. Total RNA was extracted from $60 \mathrm{mg}$ of leaf tissue using a QIAGEN RNeasy Plant Mini Kit (QIAGEN Inc., Valencia, CA) and RT-PCR was performed using a QIAGEN OneStep RT-PCR Kit (QIAGEN Inc.) in 0.2-mL PCR tubes (USA Scientific, Ocala, FL). Products of RT-PCR were purified using the QIAGEN PCR Clean-up Kit (QIAGEN Inc.) and sequenced by the dideoxynucleotide chain termination method (Sangler et al., 1977) on an ABI 3100 Automated DNA Sequencer (Applied Biosystems, Inc., Foster City, CA).

Statistical analysis. During 2005, plots with fewer than seven plants and entries with fewer than two replications on a particular date were considered missing data and were not used for statistical analysis. Severity rating and ELISA OD mean values was calculated for each entry over three replications using Proc Means statement in SAS (SAS Institute, Cary, NC). Differences between entries were estimated on each observation date using Proc General Linear Models statement in SAS. Fisher's protected least significant difference mean separation test was performed at the $5 \%$ level of significance to group the entries on the basis of averages on a particular date. Data for IYSV disease ratings were correlated with ELISA OD values in all entries using Proc Corr statement in SAS. For 2005, disease rating data collected on 7 June was correlated with the OD data of samples collected on 8 June, and disease rating data collected on 28 June was correlated with the OD data of samples collected on 28 June. In 2006, disease rating data collected on 14 June was correlated with the OD values obtained from samples collected on 13 June, and disease rating data collected on 14 July was correlated with the OD values obtained from samples collected on 17 July. Data for IYSV disease ratings and OD from 2005 were combined with that of 2006 to test the year-by-entry interaction.

\section{Results and Discussion}

By mid-April in both years, plants exhibited a few small, elongated, irregularshaped chlorotic spots at different sites on the leaves. These lesions expanded and became light yellow during the next 2 weeks. By the last week of May, these spots had turned necrotic and appeared as elongated, eyeshaped or irregular, straw-colored lesions. Eventually, leaves began to curl and twist at the site on the leaf where the IYSV lesions occurred. IYSV symptom severity increased during the growing season from a trial mean of 1.6 on June 1 to 5.2 on July 6 , the last evaluation.

Tissue samples that showed a positive reaction in ELISA with polyclonal antisera against IYSV were used for RT-PCR testing. 
The RT-PCR assays amplified a fragment of the expected size with primer pair, IYSVP1 and IYSVP2, from ELISA-positive samples. This fragment showed more than 99\% sequence identity with the IYSV NP gene sequence from an IYSV isolate from Jefferson County, OR (Genebank Accession No. DQ233479) and confirmed the presence of IYSV. RT-PCR was used to confirm the presence of IYSV in the study rather than confirming IYSV presence in every plant sample expressing a positive ELISA sample. No amplification was detected from tissue samples of the healthy control.

Entries exhibited different responses with respect to IYSV susceptibility and ELISA OD from year to year. A significant yearby-entry interaction was observed for IYSV severity ratings for all rating dates except 22 June 2006. For this reason, entry results for each year are discussed separately rather than averaged over years. There are many instances in which a particular entry changed rank from 1 year to the next with respect to both IYSV disease rating and OD.

In 2005, significant differences in IYSV disease symptom severity occurred among entries on all assessment dates except 21 June (Table 1). NMSU 04-44-1 (1.1), NMSU 0452-1 (1.2), and NMSU 04-87-1 (1.2) had significantly less severe IYSV symptoms than NMSU 04-41 (1.8), 'Caballero' (1.8), 'Excursion' (1.8), 'Candy' (1.9), and 'Madero' (2.0). 'Madero' had significantly more severe IYSV symptoms than nine other entries. On 7 June, NMSU 04-52-1 (1.4), NMSU 03-52-1 (1.6), and NMSU 04-87-1 (1.6) had significantly less severe IYSV symptoms than those with the most severe symptoms that included 'Caballero' (2.6), 'Cimarron' (2.6), 'SR 4001' (2.6), NMSU 04-52-2 (2.5), and 'Candy' (2.4).

On 14 June, 'Caballero' (3.4), 'Candy' (3.8), NMSU 04-52-2 (3.3), and 'SR 4001' (3.3) exhibited again more symptoms than NMSU 03-52-1 (2.0), NMSU 04-52-1 (2.0), NMSU 04-78-1 (1.8), NMSU 04-87-1 (1.6), and 'NuMex Jose Fernandez' (2.0) (Table 1). Two weeks later on 28 June, the disease began to progress quite rapidly for some of the entries, including 'Caballero' (4.7 to 6.3), NMSU 04-57-1 (3.9 to 4.7), 'Sierra Blanca' (3.6 to 4.9), and 'SR 4001' (4.5 to 5.4). NMSU 03-52-1 (2.8), NMSU 04-87-1 (2.9), 'NuMex Centric' (3.0), and 'NuMex Jose Fernandez' (3.1) exhibited significantly the least IYSV symptoms in the trial. By the last observation date on 6 July, all entries exhibited severe disease symptoms and some entries reached bulb maturity. 'Caballero' (6.8) exhibited more disease symptoms than all but six entries. In addition, 'SR 4001' (6.4), NMSU 04-57-1 (6.2), 'Sierra Blanca' (6.0), 'Cimarron' (5.9), NMSU 04-52-2 (5.9), and NMSU 04-78-1 (5.9) exhibited more symptoms than five other entries. NMSU 03-52-1 (4.0), NMSU 04-41 (4.3), NMSU 04-44-1 (4.5), NMSU 04-87-1 (4.5), 'NuMex Jose Fernandez' (4.6), and 'Rumba' (4.6) exhibited the least symptoms at this sampling date. Overall, NMSU 04-87-1, NMSU 03-521 , and 'NuMex Jose Fernandez' had the lowest IYSV severity during 2005, whereas 'Caballero' had the most followed by 'Cimarron' and 'SR 4001'.

In 2006 , at the first disease rating on 8 June, values were less than two and there were no differences among entries (Table 1). The next week, subtle differences were observed between entries. 'Cimarron' (2.1) and 'Excursion' (2.0) exhibited more symptoms than 10 other entries, whereas NMSU 03-52-1 (1.4) and 'Candy' (1.5) exhibited fewer symptoms than eight other entries. On 22 June, 'Excursion' (2.8) and NMSU 0452-1 (2.7) exhibited more symptoms than all other entries, except 'Candy' (2.3), 'Cimarron' (2.3), and 'Madero' (2.3), whereas 'NuMex Centric' (1.6) and 'Caballero' (1.6) exhibited significantly fewer symptoms. By 29 June, 'Excursion' (3.2) exhibited more disease symptoms than all other entries, except 'Cimarron' (3.0) and 'Sierra Blanca' (2.7). In addition, 'Cimarron' exhibited more symptoms than 13 other entries. Conversely, NMSU 03-52-1 (1.8) and NMSU 04-44-1 (1.8) exhibited fewer symptoms than eight other entries. By 5 weeks on 6 July, a rapid progression of disease development occurred for 'Candy' (2.6 to 4.6), NMSU 04-87-1 (2.1 to 4.1), 'NuMex Jose Fernandez' (2.3 to 3.9), and NMSU 03-52-1 (1.8 to 3.3). At this date, 'Candy' exhibited more symptoms (4.6) than all other entries except 'Cimarron' (4.1), NMSU 04-87-1 (4.1), and 'NuMex Jose Fernandez' (3.9). In addition, plants of 'Cimarron' and NMSU 04-87-1 exhibited more symptoms than plants of seven other entries. All of these entries had significantly higher IYSV ratings than the best varieties, NMSU 04-52-2 (2.3), NMSU 04-57-1 (2.4), 'SR 4001' (2.5), NMSU 04-44-1 (2.6), and 'Caballero' (2.7). On the last observation date of 14 July, another large increase in symptom severity was observed from the previous week with the mean IYSV ratings increasing from 3.3 on 6 July to 7.2 on 14 July. Most entries were rated high for disease severity and exhibited an equal amount of disease at this time. NMSU 04-52-1 (8.3) and NMSU 04-57-1 (8.1) exhibited more disease symptoms than five other entries. NMSU 0352-1 (4.6) exhibited fewer symptoms than all other entries followed by NMSU 04-41 (5.9), NMSU 04-44-1 (6.3), and 'NuMex Jose Fernandez' (6.6) that exhibited fewer symptoms than seven other entries. Overall, NMSU 03-52-1, NMSU 04-44-1, and 'SR 4001' had the least severe IYSV symptoms during the 2006 season, whereas 'Cimarron', 'Excursion', and 'Candy' had the most severe IYSV symptoms.

When averaged over both years, NMSU 03-52-1, NMSU 04-41, NMSU 04-44-1, and 'NuMex Jose Fernandez' exhibited fewer symptoms than most other entries by the last observation date. These four entries show the most promise for developing IYSV-resistant or -tolerant cultivars. 'NuMex Jose Fernandez' is a released cultivar (Corgan, 1994), whereas the other three entries are breeding lines in the NMSU onion breeding program. Both 'Ben Shemen' and 'Peckham Yellow
Sweet Spanish' onion cultivars were used in the development of 'NuMex Jose Fernandez' (Corgan, 1994) and NMSU 03-52-1 in addition to other cultivars that were different for the two entries. These two onion cultivars may be conferring some level of IYSV tolerance to the two tested entries.

In future screenings, entries should be grouped based on similar bulb maturity time. As plants near maturity, leaf senescence may enhance IYSV symptom expression or may be confused with IYSV symptoms. In addition, later-maturing entries or plants may express few IYSV symptoms or may appear to have fewer symptoms for their leaf mass than earlier maturing entries and thus appear to be more IYSV-resistant or -tolerant. In this instance, symptom expression and apparent resistance to internal proliferation of the virus or tolerance to the virus in the form of normal plant growth in the presence of the virus may be more a function of physiological age rather than true resistance or tolerance. By grouping entries based on their bulb maturity time, entries with more IYSV tolerance would be easier to identify. In this study, 'NuMex Jose Fernandez' matures 2 weeks earlier than NMSU 03-52-1 and NMSU 0441 and shows great promise for IYSV tolerance of early-maturing, winter-sown yellow onion cultivars.

With the screening objectives in mind for this study, disease symptom expression in commercial onion fields would be expected to be less and the onset of disease to be delayed as compared with our experimental fields. Commercial fields would contain lower onion thrips populations and IYSV pressure and the crop would be grown under less stressful conditions. The entries tested in the study would be expected to perform better in commercial onion fields.

Several trends for disease progression over time were observed in both years. In 2005, for 'Caballero', 'Cimarron', NMSU 04-52-2, and 'SR 4001', the disease progressed at a rapid rate, and these entries exhibited more symptoms than most entries at each observation date. In 2006, the disease progressed at a rapid rate for 'Candy', 'Cimarron', and 'Excursion', which exhibited greater disease symptoms than most entries at each observation date. In both years, NMSU 04-57-1 and NMSU 0478-1 had some of the least severe IYSV symptoms early in the season, but then had some of the highest severity ratings on the last observation. In both years, NMSU 03-52-1, NMSU 04-41, NMSU 04-44-1, and 'NuMex Jose Fernandez' consistently had some of the lowest IYSV severity ratings throughout the season and the lowest ratings on the final observation. With regard to disease development over time, the disease developed steadily in these entries. This development pattern suggests that selecting for IYSV resistance or tolerance might be more effective by searching for entries that develop symptoms slowly rather than those entries that develop symptoms rapidly. Assuming uniform disease and timing of IYSV establishment, the most accurate time to identify IYSV tolerance 
would be to assess IYSV symptom severity at the end of the season.

In future screenings, disease ratings conducted on the same plants in the plots at each rating date would be helpful for assessing disease development over time. In our study, arbitrarily selected plants were rated within the test plot at each rating date. It is highly likely that different plants were being rated from 1 week to the next. By rating the same plants on a weekly basis, plant-to-plant variation in symptom expression over time would be reduced on a plot basis.

Two entries performed differently from year to year. NMSU 04-52-1 had low to moderate IYSV severity ratings throughout 2005 and for most of 2006 until the last observation when it had one of the most severe IYSV ratings in the trial. 'SR 4001' had some of the most severe symptoms throughout 2005 and some of the least severe symptoms in 2006 . From a breeding perspective, germplasm that exhibits a low amount and stable symptom expression over years is more desirable for disease resistance/tolerance development than germplasm that varies greatly year to year in its symptom expression. Like with many foliar diseases, symptom expression of IYSV is partially dependent on environmental conditions (i.e., temperature, moisture) that influence plant stress levels and onion thrips fecundity (Gent et al., 2006). These environmental conditions can vary year to year and can vary within a single year or season. It is expected that IYSV symptom expression will vary from year to year (Shock et al., 2008) and also in the timing of onset within a single year.

For OD values, no differences were observed among entries in 2005 (data not shown). The mean OD values for each sampling date in 2005 were 0.051 and 0.096 for 7 June and 28 June, respectively (data not shown). These values were greater than those of the healthy control, 0.004 and 0.006, respectively, for the same sampling dates (data not shown). These results would indicate that entries were infected with IYSV. For 2006, differences were observed between entries for OD values at both sampling dates (Table 2). On 12 June, plant samples from NMSU 04-44-1 exhibited a higher OD than plant samples from all other entries. Plant samples from NMSU 03-52-1 and 'NuMex Jose Fernandez' had the lowest OD. As compared with the healthy control, all of the entries would be considered positive for IYSV. On 17 July, samples from NMSU 0457-1 and NMSU 04-44-1 exhibited a higher OD than samples from seven other entries. Conversely, samples from 'NuMex Centric' exhibited a lower OD than plant samples from seven other entries. As compared with the healthy control, all of the entries would be considered positive for IYSV. As mentioned earlier, grouping entries together based on their relative bulb maturity when designing future experiments may be helpful for comparing OD values between entries because the physiological age differences between entries may influence virus titer within plants.

No correlation was observed between average OD and average disease rating of entries in either year (data not shown). Optical density was not a good predictor for disease severity. For example, NMSU 0444-1 had some of the highest OD readings,

Table 2. Enzyme-linked immunosorbent assay (ELISA) optical density (OD) values ${ }^{\mathrm{z}}$ of tissue samples collected from the indicated entries over the crop season in 2006 and the amount (in parentheses) that the value is greater than the healthy control OD value plus four sDs of the control OD value.

\begin{tabular}{|c|c|c|c|c|}
\hline \multirow[b]{2}{*}{ Entry } & \multicolumn{4}{|c|}{ Field sampling date } \\
\hline & \multicolumn{2}{|c|}{12 June } & \multicolumn{2}{|c|}{17 July } \\
\hline Caballero & 0.034 & $(2.04)^{y}$ & 0.319 & $(3.50$ \\
\hline Candy & 0.025 & $(1.50)$ & 0.282 & $(3.09$ \\
\hline Cimarron & 0.039 & $(2.34)$ & 0.202 & $(2.21$ \\
\hline Excursion & 0.028 & (1.68) & 0.234 & $(2.57$ \\
\hline Madero & 0.035 & $(2.10)$ & 0.207 & $(2.27$ \\
\hline NMSU 03-52-1 & 0.021 & $(1.26)$ & 0.272 & $(2.98$ \\
\hline NMSU 04-41 & 0.031 & $(1.86)$ & 0.243 & $(2.66$ \\
\hline NMSU 04-44-1 & 0.161 & $(9.64)$ & 0.403 & $(4.42$ \\
\hline NMSU 04-52-1 & 0.043 & $(2.57)$ & 0.370 & (3.37 \\
\hline NMSU 04-52-2 & 0.032 & $(1.92)$ & 0.375 & (4.11) \\
\hline NMSU 04-57-1 & 0.042 & $(2.51)$ & 0.421 & $(4.62$ \\
\hline NMSU 04-78-1 & 0.047 & $(2.81)$ & 0.215 & $(2.36$ \\
\hline NMSU 04-87-1 & 0.032 & (1.92) & 0.201 & $(2.20$ \\
\hline NuMex Centric & 0.041 & $(2.46)$ & 0.161 & $(1.77$ \\
\hline NuMex Jose Fernandez & 0.021 & $(1.26)$ & 0.313 & $(3.43$ \\
\hline Rumba & 0.073 & $(4.37)$ & 0.385 & $(4.22$ \\
\hline Sierra Blanca & 0.027 & $(1.62)$ & 0.282 & (3.09 \\
\hline SR 4001 & 0.062 & $(3.71)$ & 0.302 & $(3.31$ \\
\hline Least significant difference $5 \%$ & $0.051 * *$ & & $0.142 *$ & \\
\hline Positive control & 0.040 & & 0.143 & \\
\hline Healthy control & 0.009 & & 0.040 & \\
\hline Buffer control & 0.000 & & 0.000 & \\
\hline
\end{tabular}

${ }^{\mathrm{z}}$ Each cell shows the mean ELISA OD value for an entry obtained by averaging the OD values of three different tissue samples taken from three replicated plots of that entry.

${ }^{\mathrm{y}}$ Values in parentheses are the amount that the entry is greater than the healthy control +4 sD, i.e., Caballero value for 12 June is 2.04 times greater than the healthy control +4 SD.

*, **Significant F-test (17 df) at $P=0.05, P=0.01$, respectively. but also had the least severe IYSV symptom expression for both sampling dates. The lack of correlation suggests that other factors such as plant stress may be more of a determining factor in disease severity than apparent virus levels. In the future, sampling of the same plants in the plot over time would be helpful for examining a change in OD values over time. In addition, disease rating and sampling of the same plants within the plot would provide a better estimate for the correlation of these two traits.

\section{Literature Cited}

Allen, J.K.M., C.D. Scott-Dupree, J.H. Tolman, and C.R. Harris. 2005. Resistance of Thrips tabaci to pyrethroid and organophosphorus insecticides in Ontario, Canada. Pest Manag. Sci. 61:809-815.

Copeland, R. 1998. Assaying levels of plant virus by ELISA, p. 455-460. In: Foster, G.D. and S.C. Taylor (eds.). Methods in molecular biology, Vol. 81: Plant virology protocols: From virus isolation to transgenic resistance. Humana Press, Totowa, NJ.

Corgan, J.N. 1994. 'NuMex Jose Fernandez' and 'NuMex Bolo' onions release notice. NM State Univ. Agr. Expt. Stn., Las Cruces, NM.

Corgan, J.N., M.M. Wall, C.S. Cramer, T. Sammis, B. Lewis, and J. Schroeder. 2000. Bulb onion culture and management. New Mexico Coop. Ext. Serv. Circ. 563.

Cortês, I., I.C. Livieratos, A. Derks, D. Peters, and R. Kormelink. 1998. Molecular and serological characterization of Iris yellow spot virus, a new and distinct tospovirus species. Phytopathology 88:1276-1282.

Cosmi, T., E. Marchesini, and G. Martini. 2003. Presence and spread of tospovirus and thrip vectors in Veneto. Info. Agrario 59:69-72.

Coudriet, D.L., A.N. Kishaba, J.D. McCreight, and W.G. Bohn. 1979. Varietal resistance in onions to thrips (Thysanoptera, Thripidae). J. Econ. Entomol. 72:614-615.

Creamer, R., S. Sanogo, A. Moya, J. Romero, R. Molina-Bravo, and C. Cramer. 2004. Iris yellow spot virus on onion in New Mexico. Plant Dis. 88:1049.

Crowe, F.J. and H.R. Pappu. 2005. Outbreak of Iris yellow spot virus in onion crops in central Oregon. Plant Dis. 89:105.

du Toit, L.J., H.R. Pappu, K.L. Druffel, and G.Q. Pelter. 2004a. Iris yellow spot virus in onion bulb and seed crops in Washington. Plant Dis. 8:222

du Toit, L.J., G.Q. Pelter, and H.R. Pappu. 2004b. IYSV challenges to the onion seed industry in Washington, p. 213-217. In: Swift, C. (ed.). Proc. 2004 Natl. Allium Res. Conf. Grand Junction, $\mathrm{CO}$.

Gent, D.H., H.F. Schwartz, and R. Khosla. 2004. Distribution and incidence of Iris yellow spot virus in Colorado and its relation to onion plant population and yield. Plant Dis. 88:446-452.

Gent, D.H., L.J. du Toit, S.F. Fichtner, S.K. Mohan, H.R. Pappu, and H.F. Schwartz. 2006. Iris yellow spot virus: An emerging threat to onion bulb and seed production. Plant Dis. 90:14681480

Gera, A., J. Cohen, R. Salomon, and B. Raccah. 1998. Iris yellow spot tospovirus detected in onion (Allium cepa) in Israel. Plant Dis. 82:127.

Hoepting, C.A., J. Allen, K. Vanderkooi, M. Hovius, H.R. Pappu, and M.R. McDonald. 2008. First report of Iris yellow spot virus on onion in Canada. Plant Dis. 92:318. 
Hoepting, C.A., H.F. Schwartz, and H.R. Pappu. 2007. First report of Iris yellow spot virus on onion in New York. Plant Dis. 91:327.

Hoffmann, M.P., C.H. Petzoldt, and A.C. Frodsham. 1996. Integrated management for onions. New York State IPM Program Publication No. 119.

Huchette, O., C. Bellamy, R. Filomenko, B. Pouleau, S. Seddas, and H.R. Pappu. 2008. Iris yellow spot virus in shallot and onion in France. Plant Health Prog. doi: 10.1094/PHP-2008-0610-01-BR.

Jones, H.A., S.F. Bailey, and S. Emsweller. 1934. Thrips resistance in onion. Hilgardia 8:215-252.

Kritzman, A., M. Lampel, B. Raccah, and A. Gera. 2001. Distribution and transmission of Iris yellow spot virus. Plant Dis. 85:838-842.

Miller, M.E., R.R. Saldana, M.C. Black, and H.R. Pappu. 2006. First report of Iris yellow spot virus on onion (Allium cepa) in Texas. Plant Dis. 90:1359.

Mohan, S.K., J.H. Moyer, V. Bijman, L. Jensen, and B. Geary. 2002. Incidence of Iris yellow spot virus in onion bulb crops in Treasure valley region of Idaho and Oregon, p. 19. In: Proc. 2002 National Allium Res. Conf., Pasco, WA.

Molenaar, N. 1984. Genetics, thrips (Thrips tabaci L.) resistance and epicuticular wax characteristics of nonglossy and glossy onions (Allium cepa L.). PhD Diss., Univ. of Wisconsin, Madison, WI.

Mullis, S.W., D.B. Langston, Jr., R.D. Gitaitis, J.L. Sherwood, and A.S. Csinos. 2004. First report of Vidalia onion (Allium cepa) naturally infected with Tomato spotted wilt virus and Iris yellow spot virus (family Bunyaviridae, genus Tospovirus) in Georgia. Plant Dis. 88:1285.
Nagata, T., A.C.L. Almeida, R. de O. Resende, and A.C. de Avila. 1999. The identification of the vector species of iris yellow spot tospovirus occurring on onion in Brazil. Plant Dis. 83:399.

Nault, B.A., C.L. Hsu, E.A. Smith, A.M. Shelton, M. Fuchs, C.A. Hoepting, and A. DiTommaso. 2008. Identifying sources of Iris yellow spot virus in New York's onion cropping systems, 67-70. In: Boyhan, G. (ed.). Proc. 2008 Nat. Onion Res. Conf., Savannah, GA.

Nischwitz, C., R.D. Gitaitis, S.W. Mullis, A.S. Csinos, D.B. Langston, and A.N. Sparks. 2007. First report of Iris yellow spot virus in spiny sowthistle (Sonchus asper) in the United States. Plant Dis. 91:1518.

Pappu, H.R. and M.E. Matheron. 2008. Characterization of Iris yellow spot virus from onion in Arizona. Plant Health Prog. doi: 10.1094/PHP2008-0711-01-BR.

Poole, G.J., H.R. Pappu, R.M. Davis, and T.A. Turini. 2007. Increasing outbreaks and impact of Iris yellow spot virus in bulb and seed onion crops in the Imperial and Antelope Valleys of California. Plant Health Prog. doi: 10.1094/ PHP-2007-0508-01-BR.

Pozzer, L., I.C. Bezerra, R. Kormelink, M. Prins, D. Peters, R. de O. Resende, and A.C. de Avila. 1999. Characterization of a tospovirus isolate of Iris yellow spot virus associated with a disease in onion fields in Brazil. Plant Dis. 83:345-350.

Sampangi, R.K., S.K. Mohan, and H.R. Pappu. 2007. Identification of new alternative weed hosts for Iris yellow spot virus in the Pacific Northwest. Plant Dis. 91:1683.
Sangler, F., S. Nicklen, and A.R. Coulson. 1977. DNA sequencing with chain terminating inhibitors. Proc. Natl. Acad. Sci. USA 74:5463-5467.

Schwartz, H.F., W.M. Brown, Jr., T. Blunt, and D.H. Gent. 2002. Iris yellow spot virus on onion in Colorado. Plant Dis. 86:560.

Schwartz, H.F., D.H. Gent, S.F. Fichtner, R.W. Hammon, and R. Khosla. 2005. Integrated management of Iris yellow spot virus in onion, p. 207-212. In: Swift, C. (ed.). Proc. 2004 Natl. Allium Res. Conf., Grand Junction, CO.

Schwartz, H.F., K. Otto, S. Szostek, C. Boateng, W.S. Cranshaw, M.A. Camper, and L. Mahaffey. 2008. Thrips and IYSV sources in Colorado onion production systems, p. 44-47. In: Boyhan, G. (ed.). Proc. 2008 Nat. Onion Res. Conf., Savannah, GA.

Shelton, A.M., B.A. Nault, J. Plate, and J.Z. Zhao. 2003. Regional and temporal variation in susceptibility to lambda-cyhalothrin in onion thrips, Thrips tabaci (Thysanoptera:Thripidae), in onion fields in New York. J. Econ. Entomol. 96:1843-1848.

Shock, C.C., E.B.G. Feibert, L.B. Jensen, S.K. Mohan, and L.D. Saunders. 2008. Onion variety response to Iris yellow spot virus. HortTechnology 18:539-544.

Ward, L.I., Z. Perez-Egusquiza, J.D. Fletcher, F.M. Ochoa Corona, J.Z. Tang, L.W. Liefting, E.J. Martin, B.D. Quinn, H.R. Pappu, and G.R.G. Clover. 2008. First report of Iris yellow spot virus on Allium cepa in New Zealand. New disease reports. 30 Mar. 2009. <http://www. bspp.org.uk/ndr/july2008/2008-43.asp>. British Society for Plant Pathology. 